\title{
State legal regulation of the sphere of agriculture in Russia
}

\author{
Olga Kichalyuk $^{1 * *}$ and Oksana Morozova ${ }^{1}$ \\ ${ }^{1}$ Institute of Service and Entrepreneurship (branch) of DSTU in Shakhty, 147, Shevchenko str. \\ 346500, Shakhty, Russia
}

\begin{abstract}
The article examines the issues of state and legal regulation of the agricultural sector of the Russian Federation, as a basic component of the country's agro-industrial complex, at the present stage. The authors analyze the problems associated with the peculiarities of the regulatory support of the agricultural sector, focus on the priorities of the state socioeconomic policy in the current conditions of the need for import substitution, including agricultural products. The article examines the methods and limits of government intervention in agricultural production. The most effective methods of state influence and stimulation of the subjects of agrarian legal relations in order to attract highly qualified personnel to the field of agriculture are analyzed.
\end{abstract}

\section{Introduction}

The development of agriculture for the Russian Federation was and is one of the priority directions of the state socio-economic policy. Most of the territories of our country are a zone of risky farming, which is due to difficult natural and climatic conditions. As noted Kopteva, L., Romanova, I., Kulakova, S. "Agriculture is such an industry that brings prosperity to those who can work efficiently and make right decisions under high uncertainty, which may imply unsteady weather conditions, market environment, various production risks. Successful development of agriculture requires the ability to forecast and prevent unfavorable situations" [1]. In this regard, the issues of state regulation of the agricultural sector as a basic component of the agro-industrial complex as a whole are the subject of constant scientific discussions. The most important element of the organization of the economy is the market, which, in turn, is subject to certain rules of the game, and in a free market there are objective shortcomings, which are smoothed out by state intervention in market relations. The interaction of the state, economy and society is implemented as follows: the state regulates and stimulates the economy and promotes the organization of society, the economy determines the capabilities of the state and forms the economic interests of society, society, in turn, educates the state, indicates to business the goals and limitations of development. As noted, Bazenov, A.B., Begzhan, A.M., Zhunissov, Z.S., Tazhikov, A.K., Amandossuly «the transitional stage in the agrarian economy requires an optimal combination of state protection and market levers. At present, the state regulatory influence on the development of the agricultural economy remains, on the one hand, quite significant, and on the other, insufficiently effective. There is no systemic integrity in the practice of state regulation of the agricultural sector» [2].

\footnotetext{
* Corresponding author: olga.kichalyuk@mail.ru
} 
In developed countries, the state corrects those shortcomings that are inherent in the market mechanism and which either it is unable to cope with, or the decisions it makes are not effective. The state assumes responsibility for creating equal conditions for rivalry between entrepreneurs, for effective competition, and for limiting the power of monopolies. It also takes care of the production of a sufficient amount of public goods and services, since the market mechanism is not able to adequately meet the needs of the people. The participation of the state in the economy is also dictated by the fact that the market does not provide a socially fair distribution of income, and the state also needs to pay attention to the field of fundamental scientific developments, since for private entrepreneurs it is expensive and risky. As V.A. Shkarupa "Digitalization is a trend of modern economic development" [3]. Since the market does not guarantee the right to work, the state has to regulate the labor market and take measures to reduce and prevent unemployment.

State regulation of the agricultural sector is expressed, first of all, in monitoring the situation in the market and, as a consequence, in the prevention of negative processes.

\section{Legal and regulatory framework for the regulation of agriculture in Russia}

The basic normative act that defines the strategy for the development of agriculture is the Federal Law of December 29, 2006 No. 264-FZ "On the Development of Agriculture" [4]. Legal regulation of relations in the field of agricultural development, sustainable development of rural areas is carried out by the specified Federal Law, other federal laws, such as: Federal Law "On Agricultural Cooperation" [5], Federal Law "On Consumer Cooperation (consumer societies, their unions) in Of the Russian Federation" [6], the Federal Law "On Peasant (Farm) Economy" [7], other regulatory legal acts of the Russian Federation, laws and other regulatory legal acts of the constituent entities of the Russian Federation, regulatory legal acts of local governments.

According to Part 1 of Art. 5 of the Law "On the Development of Agriculture", "agricultural policy is an integral part of the state socio-economic policy aimed at sustainable development of agriculture and rural areas. Sustainable development of rural areas is understood as their stable socio-economic development, an increase in agricultural production, an increase in the efficiency of agriculture, the achievement of full employment of the rural population and an increase in their standard of living, rational use of land" [4].

The main goals of the state agrarian policy are:

1) increasing the competitiveness of Russian agricultural products and Russian agricultural producers, ensuring the quality of Russian food products;

2) ensuring sustainable development of rural areas, employment of the rural population, raising the standard of living, including the remuneration of workers employed in agriculture;

3) preservation and reproduction of natural resources used for the needs of agricultural production;

4) the formation of an efficiently functioning market for agricultural products, raw materials and food, ensuring an increase in the profitability of agricultural producers and the development of the infrastructure of this market;

5) creating a favorable investment climate and increasing the volume of investments in agriculture;

6) monitoring the price index for agricultural products, raw materials and the index of prices (tariffs) for industrial products (services) used by agricultural producers, and maintaining the parity of the indices of such prices (tariffs) [4]. 
Of course, the functioning of agriculture in any country is necessary in order to provide the population with agricultural products, the production of which is ensured through animal husbandry, fishing and crop production.

However, the development trend of the agro-industrial complex in the current conditions does not look, in our opinion, optimistic. There is a significant gap in the standard of living of the population of villages and towns, the absence of a developed social infrastructure in the villages, the desire of young people to leave the village for the city due to lack of work. The main reasons for the relatively slow development of the agricultural sector are the low rates of structural and technological modernization of the industry, the renewal of fixed assets and the reproduction of the natural and ecological potential, unfavorable general conditions for the functioning of agriculture, primarily the unsatisfactory level of development, market infrastructure, which makes it difficult access of agricultural producers to the markets of financial, material and technical and information resources, finished products; financial instability of the industry due to the instability of markets for agricultural products, raw materials and foodstuffs, a shortage of qualified personnel caused by the low level and quality of life in rural areas.

In this regard, the Order of the Ministry of Agriculture of the Russian Federation of June 25, 2007 No. 342 "On the Concept for the Development of Agrarian Science and Scientific Support of the Agro-Industrial Complex of Russia until 2025" [8] is of great importance. The purpose of the Concept is to further develop agricultural science by improving the management system and the network of research institutions, deepening fundamental and priority applied research for the development of competitive scientific and technical products, strengthening the innovative process of participation of science in the development of scientific developments in production, ensuring the effective development of the agro-industrial complex of the Russian Federation. Federation. The effectiveness of the development of the agro-industrial complex of Russia, as noted in the document, is largely due to promising scientific support that meets modern requirements, carried out by agricultural science, including the organization and conduct of fundamental and priority applied research, in order to develop competitive scientific and technical products intended for development in production.

The State Program for the Development of Agriculture and Regulation of the Markets of Agricultural Products, Raw Materials and Food, approved on July 4, 2012 by Decree of the Government of the Russian Federation No. 717 (as revised on 31.12.2020), designated the provision of conditions for the development of the agro-industrial complex as one of the directions [9].

Agricultural research institutions receive grants from the Russian Foundation for Basic Research to carry out developments in the corresponding direction. For example, from January 1, 2021, a new Agroprogress grant is introduced for agricultural producers included in the unified register of small and medium-sized businesses. The maximum grant amount is RUB 30 million. Funds are allowed to be used for the acquisition or construction of new facilities for the production, storage and processing of agricultural products, for completing these facilities with equipment, agricultural machinery and special vehicles. In addition, the grant can be spent on the purchase of animals, poultry and fish stock [10].

On January 21, 2020, the President of the Russian Federation signed Decree No. 20 "On Approval of the Food Security Doctrine of the Russian Federation" [11].

It is difficult to overestimate the significance of the decrees of the head of state, which are issued in the development of existing laws. As noted by O. Kichalyuk, O. Morozova "The definition of the status of the President of the Russian Federation allows us to conclude that the head of state occupies a special place in the system of government bodies. However, this situation does not allow interpreting the power of the President of Russia as rising above all other 
branches of government."12].

Nevertheless, the Doctrine, being a strategic document that does not have an independent legal force, has the most important state, legal and political significance. It defines food security as a state in which food independence is ensured, the physical and economic availability of food for every citizen is guaranteed in the quantities necessary for an active and healthy lifestyle. In the previous version of the Doctrine, approved by an act of the head of state in 2010, the criterion of the share of products in the total volume of commodity resources of the domestic market, taking into account carry-over stocks, was used to assess food security.

In the context of increasing import substitution, the product line has been expanded, according to which the food independence of Russia is assessed. Added vegetables and melons, fruits and berries, as well as seeds of the main agricultural crops of domestic selection. The list of potential risks and threats to food security has been expanded. Added veterinary and phytosanitary risks, sanitary-epidemiological and social threats. The social threat is due to a decrease in the attractiveness of the rural way of life, which creates risks for providing the industry with qualified personnel.

Now food independence is determined by the level of self-sufficiency, which is calculated as the ratio of the volume of domestic production to the volume of domestic consumption. According to the document, the level of self-sufficiency for grain should be at least $95 \%$, for sugar - at least $90 \%$, for vegetable oil - at least $90 \%$, for meat and meat products - at least $85 \%$, for milk and dairy products - at least $90 \%$, for fish and fish products - not less than $85 \%$, for potatoes - not less than $95 \%$, for vegetables and melons - not less than $90 \%$, for fruits and berries - not less than $60 \%$, for seeds of main agricultural crops of domestic selection - not less than 75 $\%$, for table salt - not less than $85 \%$ [11].

The doctrine was adopted in the context of the task of increasing exports and achieving a positive trade balance of raw materials and food. However, the export potential will be realized taking into account the priorities of the country's self-sufficiency, as well as economic and food security within the framework of the Eurasian Economic Union. As noted Shogentsukova, Z.K., Shogentsukov, A.K. «he development of the export potential and the formation of the export policy of the region are an important process, including domestic and foreign policy components. Improving the export activity of the subject is complicated by the presence of crisis phenomena, both in the economy and in the social sphere, similar processes are observed in the agricultural sector at the present stage» [13].

The Doctrine takes into account the balance of exports and imports in various product groups. This suggests that a rational and pragmatic approach prevailed, and exports can compensate for the overproduction of certain types of products.

An important indicator of the new Doctrine is the physical availability of food. Simply put, there should be more shops and markets. However, amid the pandemic of the new coronavirus infection and the forced social distancing of citizens, people are increasingly buying food "online" even in rural areas. Therefore, it is important to develop this area, including by providing legal guarantees for both consumers and those who ensure the production and sale of food.

\section{Limits of state impact on agriculture}

Today the question boils down to how and how, with the help of what mechanisms and methods it is possible to ensure the most effective implementation by the state of its regulatory functions, in which direction it is necessary to strengthen state intervention in agricultural production and what financial possibilities should accompany such intervention, forgetting that any action must be put into legal form. 
The modernization of the system of state regulation of agrarian relations involves the improvement of the branches of law that support them, the formation of which has a phased nature, starting with the most general laws of legal regulation. Ignoring the property nature of relations associated with state regulation of agriculture, and their fragmentation lead to the fact that the branches of law that secure agrarian legal relations are separated from the property content. This gives rise to problems, inconsistencies in the agrarian economy and the branches of law that ensure it, associated with the legal consolidation and protection of the property interests of agricultural entities in the relevant property institutions. At the same time, it is necessary to reckon with the fact that the legal consolidation of the property interest of participants in agrarian relations presupposes a combination of norms that are different in legal nature, belonging to both public and private law, which are poorly coordinated, and therefore often contradict each other.

The study of property relations associated with state regulation of agriculture, as a single harmonious system, allows us to consider them not as a mass of separate institutions that have no connection with each other, but as a certain set of them, having an internal integral structure, a set based on unity and the relationship between the institutions of agrarian relations.

At the same time, it should be noted that both in legal and economic sciences, there is no single position regarding the limits of state intervention in the regulation of agrarian relations.

In the scientific literature, there is no fundamental difference between the concepts of "state regulation of the agrarian economy" and "state management of agriculture". In particular, in the Federal Law of December 28, 2009 (as amended on 12/30/2020) No. 381F3 "On the Basics of State Regulation of Trade Activities in the Russian Federation" "state regulation" is interpreted as: establishing requirements for its organization and implementation; antitrust regulation in this area; information support in this area; state control (supervision), municipal control in this area [14]. Since trading activities are most directly related to agriculture, we can use these interpretations and to understand the state regulation of agriculture. That is, the meaning of state regulation of the agricultural sector is reduced to the adoption of normative and non-normative legal acts in order to streamline, coordinate and regulate agrarian legal relations, organize control over compliance with legislative requirements for business entities, as well as the use of incentive measures and liability for violators of established requirements. Thus, the state influence on the agricultural sector as a fundamental component of the entire agro-industrial complex includes the following measures:

1) the formation of a regulatory framework, general rules for the procedure for creation, reorganization and abolition, determination of the procedure for the activities of subjects of agrarian legal relations;

2) adoption of targeted programs, doctrines and concepts for the development of the agricultural sector, including for the long term;

3) licensing, accreditation and certification of the relevant activities;

4) setting prices, tariffs, standards and quotas;

5) provision of concessional lending, granting subsidies, granting payment deferrals and guarantees of legal protection of violated rights of business entities;

6) control and supervisory activities.

Although, the example of Ukraine, according to a number of scientists, testifies to the fact that direct government subsidies to the agribusiness of this country are harmful. They spread opaquely, distort competition, cause corruption and anxiety. As a result, the interest of bona fide agricultural producers decreases. Corruption and lack of transparency lead to 
unjustified increases in prices for agricultural products. We agree that the best way of state support for agricultural production is to increase investment costs for roads or education in rural areas [15].

State regulation of agriculture is provided by both economic and legal methods. Based on the general scientific understanding of the category "method", the method of state regulation of agrarian relations should be understood as a set of economic methods through which the state influences the subjects of agriculture. It should be noted that the methods of state regulation in the economy, including agriculture, presuppose rather versatile in nature techniques and methods of influencing agricultural relations. In economic sciences, methods of administrative and market state regulation of the economy are distinguished, where the first include: the definition of strategic goals of economic development, their expression in indicative plans; government orders and government contracts for the supply of certain types of products; regulatory requirements for quality and certification of technology and products; legal administrative restrictions and prohibitions on the release of certain types of products and others, and to market methods - taxation, the level of taxation and tax benefits; resource payments, loan rates and credit benefits.

Article 6 of the Federal Law "On the Development of Agriculture" enshrines the following dynamic methods of state regulation:

1) provision of budgetary funds to agricultural producers, scientific organizations, professional educational organizations, educational organizations of higher education, which, in the process of scientific, scientific and technical and (or) educational activities, carry out the production of agricultural products, their primary and subsequent (industrial) processing in accordance with the list specified in Part 3 of Art. 3 of this Federal Law, in accordance with the legislation of the Russian Federation;

2) the application of special tax regimes in relation to agricultural producers;

3) procurement, storage, processing and supply of agricultural products, raw materials and food for state and municipal needs;

4) regulation of the market of agricultural products, raw materials and food, including customs tariff and non-tariff regulation;

5) information support of agricultural producers and other participants in the market of agricultural products, raw materials and food, as well as providing them with consulting assistance;

6) antimonopoly regulation of markets for agricultural products, raw materials and foodstuffs;

7) participation of public organizations in the formation and implementation of the state agrarian policy;

8) carrying out procurement interventions, commodity interventions in the market of agricultural products, raw materials and food, as well as mortgage transactions;

9) other measures provided by the legislation of the Russian Federation.

A few words should be said about the methods of state regulation listed in Art. 12 of the Federal Law "On the Foundations of State Regulation of Foreign Trade Activity". The dynamic methods in it include the methods of customs and tariff regulation that directly affect the property interests of the subjects of agrarian relations. The rest of the methods (non-tariff regulation, bans and restrictions on foreign trade in services and intellectual property, economic and administrative measures that contribute to the development of foreign trade) are either static or mixed (a set of various organizational and economic impacts on agricultural subjects) [16].

We see that the dynamic methods of state regulation of the agrarian economy are models of relations that affect the property interests of the subjects of agrarian relations, 
and are the most important and main part of the system of state regulation of the agrarian economy, through which the state implements its economic programs, achieving economic goals.

\section{Improving the efficiency of state legal regulation of agriculture}

Increasing the efficiency of legal regulation in agriculture should solve two important tasks:

1) further legal consolidation of state regulation of this industry, including the adjustment of the implemented methods and the correction of mistakes made;

2) strengthening the legal protection of agricultural producers, which requires a more careful correlation of the norms regulating relations in agriculture with the general provisions of the basic branches of law.

Back in 2017, the Board of the Eurasian Economic Commission, after analyzing and assessing the effectiveness of state regulation of the agrarian market and state support for agriculture, taking into account the agricultural development programs in force in the member states of the Eurasian Economic Union (EAEU), and other regulatory legal acts that form agricultural policy in the member states, the possibilities of the member states to allocate budgetary funds, made a Recommendation "On improving the efficiency of measures of state regulation of the agricultural market and state support for agriculture", based on Article 95 of the Treaty on the Eurasian Economic Union, signed on May 29, 2014 in Astana, of which the Russian Federation is a member [17]. At the present stage, the Eurasian Economic Union has enormous potential as a new international legal and evolutionary model of economic integration in the post-Soviet space. The agrarian market of the EAEU is being formed and in the future may become one of the largest regional markets in the world. The existing division of labor and the location of agricultural production in accordance with natural and climatic conditions creates objective opportunities for the development of mutually beneficial trade.

The EAEU member states occupy a significant place in the functioning of the world food market, being active participants in trade both in terms of the export of agricultural products and food, and their import.

According to the Recommendations, the member states with the assistance of the Eurasian Economic Commission are encouraged to develop the measures presented in Table 1 [18].

Table 1. Measures of state regulation of the agricultural market and state support for agriculture.

\begin{tabular}{|c|c|}
\hline Goal & Measures to achieve the goal \\
\hline $\begin{array}{l}\text { Increasing the level of } \\
\text { government support }\end{array}$ & $\begin{array}{l}\text { Stimulating innovations in the agro-industrial complex; } \\
\text { ensuring the financial and economic stability of } \\
\text { enterprises in the agro-industrial complex, carrying out } \\
\text { research and development work in order to develop } \\
\text { new technologies and solutions, as well as improving } \\
\text { the qualifications of workers in this sector; stimulating } \\
\text { investment in production, introducing control measures } \\
\text { over the timing of state support to enterprises in the } \\
\text { agro-industrial complex. }\end{array}$ \\
\hline $\begin{array}{l}\text { Agricultural } \\
\text { development }\end{array}$ & $\begin{array}{l}\text { Improving the efficiency of the system for bringing } \\
\text { products to the consumer and increasing the share of }\end{array}$ \\
\hline
\end{tabular}




\begin{tabular}{|l|l|}
\hline development & $\begin{array}{l}\text { agricultural producers in the consumer price; increasing } \\
\text { the productivity of enterprises of the agro-industrial } \\
\text { complex and the efficiency of using agricultural land; } \\
\text { stimulating the creation and development of enterprises } \\
\text { for the production of means of production for the agro- } \\
\text { industrial complex, including joint ventures of the } \\
\text { member states; improving social conditions and } \\
\text { increasing the material security of agricultural workers. }\end{array}$ \\
\hline $\begin{array}{l}\text { Support and development of the } \\
\text { infrastructure of the agri-food } \\
\text { market }\end{array}$ & $\begin{array}{l}\text { Development of capacities for storage and } \\
\text { transportation of agricultural products; stimulation of } \\
\text { the development of export support infrastructure, } \\
\text { including transport and storage facilities, information } \\
\text { support, legal and consulting services, brokerage and } \\
\text { agency operations. }\end{array}$ \\
\hline Agricultural producers training & $\begin{array}{l}\text { Improving the qualifications of farmers, their training } \\
\text { in order to prevent the spread of pests and plant } \\
\text { diseases, as well as animal diseases. }\end{array}$ \\
\hline
\end{tabular}

In the theory of economic law as a separate area of legal science, the effectiveness of legal regulation of property relations is singled out into an independent category that is not related to the final economic result. It is defined in the unity of two indicators: firstly, the legal provision of economic rights and freedoms, and secondly, the criterion for restraining and suppressing the accompanying negative behavior. At the same time, the criterion of legal efficiency indicates a one-sided dependence of economic, efficiency on legal, based on the principle: effective law does not interfere with the economy, but ineffective law prevents economic development. However, since the methods of state regulation of agrarian relations as economic institutions are already selected models of property relations, the legal effectiveness of positive behavior in assessing the corresponding economic institution is reduced to the legal support of property interest. Further, various options for the behavior of the participants in the relationship are assessed, aimed at replacing the property interest, its violation: for example, contracting should be protected from the possibility of its transformation into full or partial donation due to improper actions of one of the parties, and state assistance in the form of a subsidy after a promise from the state to provide it to an agricultural commodity producer is unreasonably reduced to zero - from these negative opportunities the property interest of participants in property relations in the institution of obligations must be protected. Comparison of the above categories allows us to summarize that for the methods of state regulation of agrarian relations, legal support and protection of the property interests of agricultural entities is an expression of the effectiveness of legal regulation of the relevant economic institution.

For example, the Decree of the Government of the Russian Federation of August 10, 2019 No. 1796-r approved the Long-term strategy for the development of the grain complex of the Russian Federation until 2035, in accordance with which procurement and commodity interventions are included in measures of state support for domestic agricultural producers and measures of state regulation of the grain complex [19]. As a measure of state regulation, the mechanisms of state interventions can be used to reduce the volatility of the domestic market and ensure a balance of interests of agricultural producers and grain processors. To achieve these goals, it is planned to ensure the maintenance of the target volume of reserves and stocks at the level of $2-2.5 \%$ of the volume of domestic 
consumption in physical terms, which will ensure a sufficient regulatory effect on the situation in the domestic market [18]. The expediency and effectiveness of interventions have recently been actively discussed by both government officials and representatives of the business community. According to experts, the considered support measures are needed so that farmers do not sell their products below the cost price, but could sell it at prices that will ensure the production process in the future.

\section{Conclusion}

Agriculture has always been and remains the most important resource of any state, influencing the natural, economic, human and ethnocultural potential. As E. Krasnoperova notes, the Russian economy is going through difficult times [20]. There are still many unresolved problems in rural areas, and the level and quality of life of the rural population as a whole lag significantly behind the standard of living in cities. The need for state support for the agricultural sector is primarily due to economic factors. According to experts, the agricultural industry is subject to a large number of risks, since it depends on natural and climatic conditions, which significantly reduces its investment attractiveness.

In modern socio-economic conditions, the main vector of the state agrarian policy is to ensure food security. The development of production, processing, transportation, storage and sale of agricultural products is impossible without the creation of legal, economic, organizational and other conditions. State support is provided at the federal, regional and municipal levels.

In recent years, activities aimed at import substitution have been actively carried out. A wide range of whole milk products is produced in Russia, including not only drinking milk, but also fermented milk products, cheese, cottage cheese and ice cream. In the total volume of manufactured products, it should be noted that the producers of cheese and dairy products benefited from the imposed sanctions, their production volumes in 2019, compared to 2005, increased by 4.5 and 2.4 times, respectively. In the period 2005-2019, the total volume of meat production in Russia increased by $33 \%$.

The level of agricultural development is reflected in the socio-economic indicators of rural areas. So, in the period from 2005 to 2019, negative trends are observed in Russia that characterize the social function of the state: a decrease in the number of the rural population, an increase in its migration from the village, a decrease in the number of feldsher-midwife stations, and others. In general, the current situation is associated with problems of employment, lack of high earnings, less comfortable living conditions in villages, and a reduced number of social services.

Medical care for the population is one of the most important social components necessary for comfortable living in villages. In rural areas, as a rule, this function is performed not by large municipal medical institutions, but by feldsher-obstetric centers that need funding from the state [19].

In the organizations of the agricultural sector, located in areas with a high population density, there are more young specialists with basic higher education than in rural settlements remote from the regional center. Therefore, one of the directions of state influence on the development of agriculture should be measures aimed at attracting qualified personnel to remote rural areas. We are in solidarity with the position that "the digital economy offers expanded opportunities for sustainable development of the agricultural sector in the region. However, its organization should apply its own schemes, and not template schemes from other industries. In the regions of the North Caucasian Federal District of the Russian Federation, much attention to environmental responsibility, 
the introduction of "green" innovation, closed production. This creates the preconditions for the implementation of new initiatives based on the capabilities of digital technologies robots and artificial intelligence"[21]. According to Rubaeva, OD, Zubareva, IA, Pakhomova, NA, Malykhina, EA, "Human resources are the most important strategic resource for the development of digitalization of the agro-industrial complex. mechanism for achieving this goal is the main task of the state personnel policy, science and education"[22].

Regulatory support for the development of agriculture at the regional level is the most important area of implementation of the state agrarian policy. As the rule-making practice shows, only a quarter of the constituent entities of the Russian Federation adopted strategic planning documents aimed at the development of agriculture as an independent subject of state support. In the rest of the constituent entities of the Russian Federation, one can observe the fragmentation and inconsistency of the normative legal acts regulating state support of the agricultural sector.

\section{References}

1. L. Kopteva, I. Romanova, S. Kulakova, E3S Web of Conferences, 175, 13-39 (2020)

2. A. Bazenov, A. Begzhan, Z. Zhunissov, A. Tazhikov, B. Amandossuly, International Journal of Criminology and Sociology, 9, 3175-3186 (2020)

3. E. Shkarupa, Lecture Notes in Networks and Systems, 110, 173-182, (2020)

4. Federal Law of December 29, 2006 No. 264-FZ "On the Development of Agriculture" (as amended on October 15, 2020)

5. Federal Law "On Agricultural Cooperation" dated 08.12.1995 No. 193-FZ (as amended on 08.12.2020)

6. Federal Law "On Consumer Cooperatives (Consumer Societies, Their Unions) in the Russian Federation" dated 23.04.2012 No. 37 - FZ

7. Federal Law "On Peasant (Farming) Economy" of 11.06.2003 No. 74-FZ (as amended on 29.12.2020)

8. Order of the Ministry of Agriculture of the Russian Federation of June 25, 2007 No. 342 "On the Concept for the Development of Agrarian Science and Scientific Support of the Russian Agro-Industrial Complex until 2025"

9. Resolution of the Government of the Russian Federation of July 14, 2012 No. 717 (as amended of December 31, 2020) "On the State Program for the Development of Agriculture and Regulation of Markets of Agricultural Products, Raw Materials and Food"

10. Decree of the Government of the Russian Federation of November 26, 2020 No. 1932 "On Amendments to Appendices No. 7 and 8 to the State Program for the Development of Agriculture and Regulation of Markets for Agricultural Products, Raw Materials and Food"

11. Decree of the President of the Russian Federation of January 21, 2020 No. 20 "On the approval of the Doctrine of food security of the Russian Federation"

12. O. Kichalyuk, O. Morozova, Man in India, 97(23), 363-373 (2017)

13. Z.K. Shogentsukova, A.K. Shogentsukov, E3S Web of Conferences, 222, 1-12 (2020)

14. Federal Law of December 28, 2009 No. 381-FZ "On the Basics of State Regulation of Trade Activities in the Russian Federation"(as amended of December 30, 2020) 
15. S. Zakharin, S. Stoyanova-Koval, I. Kychko, V. Marhasova, I. Shupta, Journal of Optimization in Industrial Engineering, 14(1), 209-218 (2021)

16. Federal Law of 08.12.2003 No. 164-FZ "On the Basics of State Regulation of Foreign Trade Activity"(as amended on 22.12.2020)

17. Treaty on the Eurasian Economic Union "(Signed in Astana on 05/29/2014) (as revised on $10 / 01 / 2019$ )

18. Recommendation of the Board of the Eurasian Economic Commission dated November 27, 2017 No. 28 "On increasing the efficiency of measures of state regulation of the agricultural market and state support for agriculture"

19. Order of the Government of the Russian Federation of August 10, 2019 No. 1796-r "On the action plan for the implementation of the Long-term strategy for the development of the grain complex of the Russian Federation until 2035"

20. A.S. Abdulkadyrov, A.G. Buchaev, N.Y. Kazavatova, Advances in Science, Technology and Innovation, 139-144 (2021)

21. E. Krasnoperova, E3S Web of Conferences, 176, (2020)

22. O.D. Rubaeva, I. Zubareva, N. Pakhomova, E.Malykhina, Journal of Environmental Management and Tourism, 11(3), 692-703 (2020) 